\title{
時間の異方性と H定理
}

\section{長坂源一郎}

\section{1. 数学的時間と物理的時間}

良く知られているよらに, ニュートンは，観察されるいわゆる相対時間と区別 して, 数学的な, 一様に流れる絶対時間の存在を主張している。ニュートンにお ける絶対時間の重要性は, その哲学的な意味よりも、それが実数直線で表現され るととにある。ニュートン以降においては，事象を時空座標によって表現するて とは, むしろ当然のてとであり, その意味でての表現形式は, ニュートン以後の 数学的物理科学の基本的な一般的概念体系を形成するてとになったのである. 木 ワイトヘッドが批判したとてろの， らわゆる simple location の観念の基底を なすものである。 (1) マックスウェル的電磁気学をも含むところの, 広い意味での 古典的力学思想は, すべての物理量を, したがってすべての物理的事象を時空座 標の関数として表現するてとを以って根本としている。このてとは, 時空座標に よって表現される時間量, 空間量が本来的な意味での物理量ではなく, むしろ物 理量関数のパラメター的性格のものであるととを示唆するものと考えられる. 更 に, 空間量自体が時間の関数として理解されることは, 時間が, すべての物理現 象を表現するための最も基本的なパラメターであるととを示すものである．すな わち，現代的観点からするならば，ニュートンの相対時間と絶対時間との区別 は, 観測される物理量としての時間概念と, 物理量を表現するパラメターとして の時間概念との間の区別と考えるてとができる．後者が一種の理論概念であるて とは言らまでもないが，電磁場やエントロピーなどの物理量である理論概念とは 基本的に異なる性格のものであるてとが想像されるのである.

ての事情は, 運動方式を一般座標を用いて, らわゆるハミルトン形式で表わし た場合に最も良く示される。、ミルトンの運動方程式 


$$
\begin{aligned}
\frac{d q i}{d t} & =\frac{\partial H}{\partial p i}, \quad \frac{d P i}{d t}=-\frac{\partial H}{\partial q i} \\
i & =1, \cdots \cdots \cdots, f
\end{aligned}
$$

は, 任意の正準変数 $q_{i} p_{i}$ 凡対して成立する（1)において $t$ が，正準変数 $q_{i}$ prとは論理的に異なる性格のものであるてとは明らかである。原理的に力学系 は, $q_{i}, p_{i}$ の組によって指定される筈であり, もしハミルトニアン $\mathrm{H} K, \mathrm{t}$ があ らわに含まれる場合にも，正準変数 $q_{i}, q_{i}(j=f+1, \cdots \cdots \cdots \cdot \cdot$ を含む，新たなハミ ルトニアン $\mathrm{H}^{\prime}$ において $\mathrm{t}$ を消去するてとは原理的に可能な筈である。また正準 変数間に関数関係が成立するとすれば，それは境界条件ないしは法則を表現する ものとして理解される。 $q_{i}, p_{i}$ が $\mathrm{t}$ の関数であるととは, それ自体では, 法則あ るいは境界条件を表現するものではない。 ${ }^{(2)}$

とれに対し, ニュートンが相対時間と規定したととろのもの, 寸なわち物理量 として観測される時間は, 他の物理量から導かれるものである，時間の測定には 何等かの時計の存在が前提されているととを記憶しなければならない. 時計が計 器として認められるためには, 数多くの物理的現象の間の相関関係, すなわち法 則の確立が暗黙のらちに前提されている。少なくとも位置天文学における周期性 と, 振子の周期運動の回数との間の一様な相関性が確められていない限り, 振子 の回数を以て「時間」といら物理量の操作的な定義は可能ではないであろう. 物 理的な時間概念の導入には, 多くの物理量の間に存在する相関性と, てれらの物 理量による物理現象の表示に関する整合性 (coherency) の存在が必要である. ${ }^{(3)}$ とのように考えるなら，物理的時間の一様性は，むしろ定義の性格を持つもの であるととが理解されるであろう．温度を水銀の体積膨脹によって規定するとき 温度は体積に従って均質なものとなり, 数值的な表現が可能になる. 各種温度計 の間の不一致が問題とされるとを，理論概念としての温度が導入されるととにな るが，明らかにてれは，温度計による温度の理論的解明であり，そてで問題とな るのは整合性の要求である。同様に物理的時間の一様性も, 根本的には時計の目 盛の一様性に帰着されなければならない。

てれに対して, パラィターとしての時間の一様性は導かれるものでなく, 本来 
的なものである。乙てでは整合性が問題となることはない，整合性が問題となる のは，関連する種々の定義が存在するとをである，パラメターとしての時間は， それが実数系列に対応するといら以外には，どのような性質をも持つものではな 々. 限定を受けるのは, それの関数として表現されるとてろの他の物理量なので ある。

との二つの時間, 数学的時間と物理的時間の混同が一般に生じたのには, 幾つか の理由が考えられる，第一には，自然法則が微分方程式によって表現されるとい ら誤解である。もし (1) が自然法則であるならば, それに含まれる関数関係は当 然 $t$ を含み, したがって $t$ は物理量でなければならないであろら。ニュートンの 運動方程式や電磁方程式は, 自然法則のマトリックスではあっても, それ自体は法 則を表現するものではない（1）の形の微分方程式から, 我々は自然におけるいか なる法則性をも推論するととはできない，自然法則とは，物理量の間に普遍的に 成立する恒常的関係でなければならない。むし(1) から法則を導てうとするなら ば(i)正準変数 $q_{i}, p_{i}$ 凡解釈を与え，(ii)関係する物理量の $q_{i}, p_{i}$ 亿関する関数形を 決定し，(iii) $H$ 亿対し特定な仮定を導入し，かつ(iv)境界条件に関する仮定を設けな ければならないであろら，大部分の場合は，それに加えて，(1)から導かれた数学 的形式が，どの程度の不正確さ（inexdactness）の範囲内で観測に適合するかと レらことも定める必要がある. ニュートンの運動の方程式から, ガリレオの落体 の法則を導くためには，定数重力を仮定すれば良い．しかし，落体の法則が万有 引力と関連させられるととを示すととによって, 微分方程式から法則を導くとと がトリヴィアルな事でなくなるのである，そのととによって，質量といら物理量 と自然落下現象を含む無数の物理現象との間に成立する普遍的関係の存在が提示 されるととになるからである，第二には，落体の法則のように，時間を含む法則 が運動方程式から導かれるととである，との場合 $\mathrm{t} は$, 前述の如く他の物理量で 置を換えるてとがでを，また時計を力学系の中に含めるならば，そのよらな系に おいては, 時間は理論概念として導入されたものとなるであろら。てのよらな解 釈は，少なくとも慣習的には極めて人工的なものと考えられるかも知れない。 し かし例えば電流計による電流の測定と比較するとを, 物理的時間が, 少なくとも 
電流と同様な理論的性格を持つものであるととは明らかであろう．落体の法則を 導くというととは, 微分方程式の一つの解と法則とを形式的に適合させるととに よって, 数学的パラメターを物理的時間と解釈するてとに他ならないのである.

\section{2. エントロピーと時間の異方性}

てのように考えるならば，(1)における数学的時間の一様性と等方性は，定義に よって明らかなてとであって，てれを自然現象の可逆性，あるいは時間の等方性 と結びつけて考えるてとは，数学的時間と物理的時間との混同より生じたものと 考えることができる，数学的時間の一様性と等方性は，明らかに実数系列の一様 性，等方性に㷌着されなければならない，運動方程式が時間の反転に対して不変 であることは，可逆過程の存在の根拠にはならなら，もし我々が時間の異方性に ついて議論しょらとするならば，その時間は，物理時間でなくてはならないので ある。そして物理時間そのものが，物理量間の関係の整合性の要求から導入され た理論概念であると考えるとを，時間の異方性の問題は，物理過程の非可逆性の 問題に還元されなければならないであろう.

数学的時間と物理的時間との適合性が根本的に破れなら限り, 力学系は当然可 逆的である。 ${ }^{(4)}$ そして物理過程の非可逆性から物理時間の異方性が結論されると するならば，物理量としての時間を含むとてろの物理量間に存在する法則として 表現されなければならないであろら。このように考えるならば，時間の異方性は 孤立系においてェントロピーは時間の「後方」において増加し, 逆の方向におい て減少するという「事実」に基づくという，良く知られたエディントンの主張の 意味するとてろを理解するてとがでをる. ${ }^{(5)}$ もしケルビン，クラウジウスのエン トロピーによる熱力学第二法則の正式化が，真に法則としての資格を持つもので あるならば，そして物理的時間が，乙の法則に根本的な関連を持つものであるな らば，物理的時間に異方性を導入する可能性を生ずるからである.

したがって，個々のミクロ系の状態変化の可逆性を前提とするとてろの統計力 学的考察に基づくとてろのエディントンに対する批判は, ${ }^{(6)}$ 妥当なものとは考允 られない. ミクロの系を記述する時間が数学的時間である限り, 時間の異方性注 
原理的に導かれならからである。もし物理的時間の異方性が，物理系の非可逆性 から導かれるものであるならば，その非可逆性は，何よりもまず「法則的」(nomological)でなければならず，そのような法則性を持つ言明を運動方程式から導 くことは，原理的に不可能であるからである。

しかしェディントンの主張が，上述の意味における根拠を持つものでないとと も明らかである．物理的時間の異方性は究極的には，物理的時間を，他の物理量 のあらゆる可能な变化に対して増加関数となるような表現を持つ法則が得られる ととによって実現されるであろら，孤立系のエントロピー増加の主張が，ての要 求に応えるものでないてとは言う迄もない. エントロピーが，可逆過程によって 定義される以上，いわば絶対的に非可逆な過程に対しては，エントロピーを定義 することはできない. しかも物理的時間の異方性が問題となるような物理系は， 正にそのよらなものでなくてはならないのである。エントロピーが物理系を指定 する状態量であるためには，そのような状態に到達する可逆過程の存在が，一般 的に,すなわち法則的に示されなくてならないであろら.

\section{3. ボルツマンの $\mathrm{H}$ 定理と時間の異方性}

統計力学的には物理系のエントロピーSは

$$
S=-k H+S_{0} .
$$

なる関係によって表現するとされる。ことにHは，ボルッマンあるいはギブスの H関数である.

もし系が $2 f$ 個の正準変数 $q_{i}, p_{i}(i=1,2, \cdots \cdots . . . . f)$ Kよって記述されるとて ろの力学系であるとすれば， $q_{i} ， p_{i}$ は正準方程式(1)《従う， $\mathrm{H}$ 関数は，てのよ うな力学系の統計的に互いに区別されないものの集会（例えば同一エネルギーの 気体の系）について定義されるが，孤立系に関しては，Hは状態の变化に対し常 飞減少する，すなわち(2)により，系のエントロピーはその結果増加するととにな るのである，てれがボルツマンの定理である，むし系を構成するミクロの系がす べて正準方程式に従らならば，系全体は可逆的であり，てのような結論が導かれ る筈がない.ロシュミットおよびツェルメロの反論として知られているものは, 
基本的にはてのような立場からするものである.

ロシュミット，ツェルメロの反論が，かりにマクロの系に対しては成立しなく とも, 系を構成する個々のミクロの系に対しては，H定理を言らてとは出来ず，し たがってェントロピーの増加は単なる確率的主張に過ぎないてとになるでろう. そしてェントロピー増加が確率的主張であるとすれば，エントロピー減少は， 「事実上」(de facto) 起てり得る筈であって, その意味では, 法則としての非可 逆過程の存在の主張は, したがって時間の法則的異方性の主張は成立しないてと になるであろう。

上述の議論は極めて妥当なものであるにしても, 欠陥がないわけではない，第 一にての議論は, 我々がミクロの状態に関して知識を持つてとがでをる，あるい は更に，マクロの状態は，それぞれ明確に規定されているミクロの系から構成さ れているととを前提としている，第二には，上述の如を数学的時間と物理的時間 との混用が含まれている，そして第三には，たと確率的であるにしても，H定 理そのものが成立するてとが説明されていない.

したがって上述の議論は, 理論の整合性の問題として提示されなければならな 々. それイは，ミクロの系の存在とともに，ミクロの系に対しても物理的時間が （理論概念として）規定されていなくてはならないであろう．少なくとも，古典 的統計力学は（そして修正された形では, 量子論的統計力学においても), ての ことは前提とされているのである。したがってもし将来の素粒子論において, 素 過程の非可逆性が主張されるようなととになれば，上の議論はその力を失うとと になるであろら。そしてその際に問題になるのは，あくまでも物理的時間であっ て,パラメターとしての数学的時間でないてとは言う迄もない.

第三の点は, ボルッマンの主張は基本的には論理確率に基づくものであり, 主 観確率的な要素を含んでいるととを注意するととによって氷解する。すすわち $\mathrm{H}$ 定理は, ある力学的状態を前提として, エルゴード仮定を導入するてとによって 導かれたものである，ててで問題となっているのは，一つのミクロの系から成る マクロの状態と, それと異なる状態のミクロの系から成るマクロの状態との比較 である。ととに可能な他のミクロの系の状態が，マクロの系が「次に」採り得る 
状態であるといら主張において,「次に」来る状態が時間的に後の状態であると は，確率計算をする者の主張に他ならない。もし確率計算をする者にとって「次 に」来る状態が，時間的であるならば，H関数の値は「過去」に向かって減少す る筈である. この「未来」と「過去」の取り替えに対して, 数学的時間はその可 逆性によって同一の関係を保つてとになる。したがってボルツマンのH定理は, 根本的には, 物理的時間と数学的時間との別を暗黙のらちに用んるととによって 得られたものである。

注

(1) A. N. Whitehead: Science and the Modern World (1928)

(2) 微分方程式に現われる变数あるいは定数のパラメター的性格は, 時空座標の 関 数 と しての波動関数の観念において最も明確に表明されている. 波動関数のパラメターと しての時間あるいは空間座標は, 物理量をあらわすオブザーバブルとは全く異なる資 格を持つものである. 更にパラメターと物理量との間沉数值的, 形式的適合性が存在 しなければならないといら主張が, 物理学理論に固有なものではないといらととの根 拠としては，例えば質量あるいは電荷の再正規化 (renormalization)を挙げるととがで きよう。このような理論が, 将来の理論においてどのような評価を受けるかというと とが問題なのではない. パラメターとしての数学的時間と物理量としての物理的時間 の一致が, 単に慣習的なものに過ぎず，てれを区別する理論が常に可能であるといら ことが問題なのである.

（3）整合性の考えは，1930年代のカルナップの「真理の整合性理論」(coherence theory of truth) において最も強力に述べられている. 少なくともての立場からすれば, いわ ゆるプロトコール言明といえども, 仮説以上の資格を有するものでなく, 我々の直 接 経験を記述するとてろのプロトコール言明のらち, どのよらなものが科学的認識の基 盤として採用されるかの規準を与えるものは, 関係する言明間の整合性である（例え ば, C. Hempel: “On the Logical Positivists' Theory of Truth”, Analysis II, (1935) p. 49 参照).

(4) グリュンバウムの, 「非可逆過程の存在から導かれる時間の異方性は, 時間の二つの 対立する意味（時間の二つの方向性）の間に存在する単なる構造的差異にあり, 二つ の意味の一つを, 時間の方向として採り出す根拠を与えるものでない」一-A. Grünbaum, Philosophical Problems of Space and Time, London (1964) p. 210—という 主張は, 数学的時間が, 非可逆性が問題となるところの物理的時間とは別て構想され たものであることを考えるならば当然のととであると考えられるであろら.

(5) A. S. Eddington, The Nature of the Physical World, New York(1928), p. 69以下.

(6) 例えば A. Grünbaum: loc. cit. p. 220 .

(7) ibid. p. 245 以下.

(南山大学) 